University of Nebraska - Lincoln

DigitalCommons@University of Nebraska - Lincoln

Library Philosophy and Practice (e-journal)

Libraries at University of Nebraska-Lincoln

February 2021

\title{
Provision of Alternative Formats of Information Resources for Inclusive Library Services of Visually Impaired Primary School Pupils in Southeast Nigeria
}

\author{
Esther Ekene Aghauche PhD \\ Department of Library and Information Science Nnamdi Azikiwe University, Awka, Nigeria, \\ ee.aghauche@unizik.edu.ng \\ Obiora Kingsley Udem PhD \\ Department of Library and Information Science Nnamdi Azikiwe University, Awka, Nigeria, \\ ok.udem@unizik.edu.ng \\ Stephen Ikenna Aghauche \\ Department of Library and Information Science Nnamdi Azikiwe University, Awka, Nigeria, \\ aghauchestee@gmail.com
}

Follow this and additional works at: https://digitalcommons.unl.edu/libphilprac

Part of the Library and Information Science Commons

Aghauche, Esther Ekene PhD; Udem, Obiora Kingsley PhD; and Aghauche, Stephen Ikenna, "Provision of Alternative Formats of Information Resources for Inclusive Library Services of Visually Impaired Primary School Pupils in Southeast Nigeria" (2021). Library Philosophy and Practice (e-journal). 4969.

https://digitalcommons.unl.edu/libphilprac/4969 


\title{
Provision of Alternative Formats of Information Resources for Inclusive Library Services of Visually Impaired Primary School Pupils in Southeast Nigeria
}

\author{
Esther Ekene Aghauche (PhD) \\ Department of Library and Information Science \\ Nnamdi Azikiwe University, Awka, Nigeria \\ ee.aghauche@ unizik.edu.ng \\ Obiora Kingsley Udem $(\mathrm{PhD})$ \\ Department of Library and Information Science \\ Nnamdi Azikiwe University, Awka, Nigeria \\ ok.udem@unizik.edu.ng \\ $\&$ \\ Stephen Ikenna Aghauche \\ Department of Library and Information Science \\ Nnamdi Azikiwe University, Awka, Nigeria \\ aghauchestee@gmail.com
}

\begin{abstract}
This paper sought to determine the provision of alternative formats of information resources for inclusive library services of visually impaired primary school pupils in Southeast Nigeria. The study adopted a descriptive survey research design. The population of the study was 129 respondents, comprising of 125 visually impaired pupils and four librarians from the four special education centres in Southeast Nigeria. One research question guided the study. Two instruments were used for data collection which includes an observation checklist, and interview guide. Data collected with the checklist were analyzed using frequency counts, while those from interviews were analyzed qualitatively and integrated into the discussion of findings. The findings showed that alternative formats of information resources such as Braille textbooks and audio collections were not provided in many subjects in the libraries under study. Braille textbooks in almost all the subjects taught in the schools, including core subjects like English language and mathematics were not available. Even the ones available were old editions of textbooks. Also, it was revealed that other information resources except storybooks were scantly provided in alternative formats. Hence, the study concluded that the provision of alternative formats of information resources in special education centre libraries in Southeast Nigeria is inadequate. Based on the findings, it was recommended among others that the government should have a written policy statement on the provision of alternative formats of information resources for the visually impaired so that it will serve as a guide for the provision of information resources to special education centres, in order to ensure inclusive library services for the visually impaired.
\end{abstract}

Keywords: Provision, Alternative Formats, Information Resources, Inclusive Library Services, Visually Impaired, Primary School Pupils, Southeast Nigeria. 


\section{Introduction}

Visually impaired primary school pupils are pupils in primary schools with sight loss which cannot be improved by corrective lenses to enable them to read as others. Visual impairment is a disability that is associated with loss of vision. It refers to people with irremediable sight loss and it covers a range of impairments. Vision is one of the five senses of human beings and is associated with sight. The eye has different parts that work together to create the ability to see. When a part of the eye does not work right or communicate well with the brain, vision is impaired (NICHCY, 2012). Visual impairment refers to people with a wide spectrum of impairments. Ugwu (2008) asserted that it is an umbrella term referring to various degrees of defects in eye function or structure, ranging from the slightly impaired to the completely blind. Friend (2009) also opined that 'visually impaired' is a general term used to describe people who are partially sighted or completely blind. Visual impairment as pointed out by DeCarlo, Woo, and Woo (cited in Naipal \& Rampersad, 2018, p. 1) "is a condition of reduced visual performance that cannot be remedied by refractive correction (spectacles or contact lenses), surgery, or medical methods". Accordingly, it results in functional limitations of the visual system that may be characterised by irreversible vision loss, restricted visual field and decreased contrast sensitivity, increased sensitivity to glare as well as decreased ability to perform activities of daily living, such as reading or writing (Kavitha, Manumali, Praveen, \& Heralgi, 2015). However, the Copyright (Visually Impaired Persons) Act 2002, broadly defined a visually impaired person (VIP) as someone who is blind, partially sighted, and whose eyesight cannot be improved by corrective lenses to allow him or her to read without a special level or kind of light, who is unable to either hold or manipulate a book or move the eyes to be able to read easily. In other words, any person who is not able to read in a conventional way is visually impaired. Visual impairment affects how a child understands and functions in the world. It can affect a child's cognitive, emotional, neurological, and physical development by limiting the range of experiences and kinds of information a child is exposed to. This is why Eguavoen and Eniola (2007) noted that a young child with visual impairment has little reason to explore interesting objects in the environment and thus may miss opportunities to have experiences and learn and that this lack of exploration may continue until intervention. 
Visual impairment puts children in a disadvantaged position. Abosi and Ozoji (1981) pointed out the effects of blindness to be: isolation, labeling, stress, and disadvantage in the acquisition of normal experiences, loss of earning power, dependent status, loss of physical integrity, loss of confidence in the remaining senses, and loss of visual background. In other words, it affects children negatively. The traditional belief that regards children with visual impairment as those who cannot offer anything tangible and the notion that the blind are supposed to be beggars, as well as shame exhibited by families and relations of visually impaired children have affected the number going to school. Ajani (n. d.) noted that in African and Asian countries only between five and seven percent of blind children attend school. All these obstacles and negative attitudes have placed the visually impaired in a disadvantaged position in society. The nature of disability of people with visual impairment makes them more vulnerable to educational deprivation or inaccessibility, being neglected, discriminated against, and shut off from the world of information, since they are unable to see and read print materials. The most viable way to help the visually impaired persons come out of this disadvantaged position is through the provision of educational facilities, like alternative formats of information resources.

The importance of formal education to the visually impaired cannot be over-emphasized. Reasons abound why visually impaired persons should acquire education. First, education helps them overcome their visual disabilities and improve their lives and social status. Secondly, it is a means of empowering and making them become independent and self-reliant. At the same time, it enables them to contribute their quota to national development if they are employed or engaged in productive ventures. Ajani (n. d.) argued that improving life for visually impaired persons rests in education, as this is a vital gateway to job opportunities, socio-economic integration, and normalization. According to Ajani, through education, many blind people have secured high profile employment such as lawyers, judges, engineers, industrialists, teachers, to mention but a few. Formal education starts at the primary level.

The goals of primary education are: to inculcate permanent literacy and numeracy and communicate effectively; lay a sound basis for scientific and reflective thinking; give citizenship education; mold character; develop in the child the ability to adapt to changing environment; 
give the child opportunities for developing manipulative skills and provide the child with basic tools for further educational development (FRN, 2013). In pursuance of the goals of primary education, the National Policy on Education specifies school libraries as one of the educational services to be provided. School libraries play a very important role in the educational development of children by providing library and information resources for teaching and learning. Generally, libraries house information resources. A library is a collection of resources in a variety of formats that is organized by information professionals or other experts, who provide convenient physical, digital, bibliographic, or intellectual access, and offer targeted services and programmes, with the mission of educating, informing, or entertaining a variety of audiences, and the goal of stimulating individual learning and advancing society as a whole (Whole Library Handbook, n. d.). Obviously, libraries, including libraries for the visually impaired, are expected to contain a variety of resources in different formats in order to meet the varying needs of users. Provisions of information resources in the libraries play a significant role in their utilization.

Given the importance of library resources in the educational development of an individual, the extent of provision of these resources in libraries for the visually impaired especially in developing countries like Nigeria is not yet known. Library resources constitute the totality of the library holdings, which include print and non-print materials in various formats and ICT resources, with which the library meets the information needs of users. The majority of library resources are in print. Since the visually impaired cannot access information in print, there is a need to repackage information in a format suitable to them, that is, alternative formats. Alternative formats include Braille, audio/talking materials, large prints, and ICT resources. Ajobiewe (1999) was of the opinion that the provision and use of alternative formats such as Braille, large prints, talking books, and the availability of reading aids, volunteers, and transcription services in libraries servicing persons with visual impairment in Nigeria would go a long way in making information accessible to the blind and partially sighted users.

Braille, invented by Louis Braille, is the oldest format and it involves the use of the sense of touch. Braille is a system of reading and writing whereby organized raised dots are used to 
represent letters and numerals that are read by touch. It appears to be better for young people whose fingertips are more sensitive. A major problem with Braille is that its production is laborious and expensive, thus a limited quantity of materials are produced and these do not meet the needs of the increasing number of visually impaired pupils in schools. Audio/talking resources are another means by which the visually impaired access information. Audio resources involve the use of the sense of hearing. They are audio recordings on tapes, cassettes, and compact disks from books and other materials which the visually impaired can listen to, thereby providing them the opportunity of reading through listening. Audio resources are easier and less expensive to produce. They are mainly used by older people and those who met their blindness later in life. Large print materials on the other hand are materials that have their print size enlarged. They are meant to be used by people with low vision.

In recent times, Information and Communication Technology (ICT) has provided new possibilities and great potential in terms of information resources and facilities for the visually impaired. A wide range of ICT facilities also called assistive or adaptive technologies, now exist to provide access to information, giving visually impaired users equal opportunity as the sighted. ICT is a faster means of accessing information but expensive. Softwares are available to enable visually impaired learners access information. Some of this software is screen reading software e.g. JAWS, screen magnification software e. g. Zoom text and web access software e. g. Connect Outloud.

The importance of alternative formats of information resources for inclusive library services of the visually impaired cannot be over-emphasized. It is in the light of this that Adetoro (2010) asserted that information materials can only become usable to persons with visual impairment when they are transcribed into alternative formats. This implies that if information resources are not in the formats that the visually impaired can access, they are excluded from library services. In other words, the idea of inclusiveness in library services does not favour them if the resources are not available in alternative formats. 
Wehmeier (2000) refers to the word 'inclusive' as including a wide range of people. This, in simple term, means including different classes or groups of people. With regards to library services, it entails providing library services to different groups or classes of users, such as the old, young, people with special needs, children and women. These groups of users need various resources and services in order to meet their information needs. For instance, the visually impaired who cannot access information in the print form need alternative formats. Availability of alternative formats in libraries ensures that the visually impaired are carried along in the provision of library services. Inclusive library services in relation to the visually impaired entail provision of information resources and services that would enable the visually impaired access and use in the library. This involves the provision of alternative formats of Braille, audio resources large prints and ICT facilities so that the visually impaired would have equal opportunity to access information in the library as the sighted. On the hand, libraries can make arrangement for local production of these alternative formats by providing Braille machines and tape recorders. Any library that claims to run inclusive library services without providing these basic necessities is just paying lip service. The nature of alternative formats demands that they be produced by specialized libraries or agencies. There are some organizations that produce information resources for the visually impaired in Nigeria. These include Niger wives Braille Book Production Centre Lagos, Anglo-Nigerian Welfare Association for the Blind (ANWAB) Lagos, Gindiri Materials Centre for the Visually Handicapped near Jos, Vocational Training Centre for the Blind Oshodi, Lagos and Hope for the Blind Zaria.

With regards to the provision of information resources, the government is expected to play a key role. Since the centres are operating on the principle of free education, it is the responsibility of government to provide alternative formats just as is the case in schools for the sighted where print resources are provided by the government. It is expected that the government procure these resources from the production centres and send them to the special schools, to ensure that the visually impaired have equal access to library resources as the sighted. The extent, to which this is done, especially in the Southeast, is yet to be determined. If these resources are provided, pupils will be highly motivated to use them. 
Provision of information resources to the visually impaired in libraries of the developed countries like America, Britain, Australia, Canada and the Netherlands is well established. They have established national libraries that adequately cater for the information needs of visually impaired readers. Library services rendered have been enhanced tremendously in volume and in formats (Iweha, 2003). The situation in Africa is in contrast. Alemna (n. d.) noted that in most African countries, established and organized library services to the visually impaired are almost non-existent. In Nigeria, the situation may not be different from other African countries. Atinmo (2000) observed that library and information services to visually handicapped persons in Nigeria were almost negligible. Atinmo pointed out that the Nigerian government has been negligent in fulfilling that part of its educational policy which promised to equalize educational opportunities for all children regardless of their physical, mental and emotional disabilities. This neglect could be in the area of providing adequate reading materials in alternative formats.

Unless information resources are provided in alternative formats, the goals of inclusive library services would be difficult to achieve with regards to visually impaired children. This is because of the majority of information resources that aid learning exists in a format they cannot access. Four special education centres/schools have been established in the Southeast zone. These are:

$\checkmark$ Special Education Centre for the Blind, Afara-Ukwu, Umuahia, Abia State.

$\checkmark$ Basden Memorial Special Education Centre, Isulo, Anambra State.

$\checkmark$ Special Education Centre, Opefia, Izzi L.G.A Ebonyi State.

$\checkmark$ Special Education Centre, Oji River, Enugu State.

Ideally, it is expected that these centres would be provided with varieties of information resources in various formats, to ensure inclusive library services of visually impaired pupils. However, the level of provision of these resources in these centres is yet to be determined. Though not much has been written on information resources provided for the visually impaired in the zone, it can be inferred that it is only through the provision of alternative formats of information resources that the information needs of visually impaired pupils can be met, thereby, achieving the goal of inclusive library service. The major task of this study therefore is to determine the provision of alternative formats of information resources for inclusive library services of visually impaired primary school pupils in Southeast Nigeria. 


\section{Statement of the Problem}

Children with visual impairment need to have access to information resources that they can explore and exploit information. This can only be achieved by providing alternative formats of information resources. Except information resources are repackaged in alternative formats that visually impaired pupils can access, they will remain cut off from the world of information and hence deprived of inclusive library services.

The level of provision of these resources in Nigeria is in doubt. In the past, efforts have been made to provide information resources generally for primary school pupils, but this unique group has special needs that may not have been given proper attention. This is why it is necessary that a study be carried out to determine the extent of provision of alternative formats of information resources in special education centres in Southeast Nigeria since this would make for inclusive library service of visually impaired pupils.

\section{Purpose of the Study}

To determine the provision of alternative formats of information resources for inclusive library services of visually impaired primary school pupils.

\section{Research Question}

What are the alternative formats of information resources provided for inclusive library services of visually impaired primary school pupils in Southeast Nigeria?

\section{Method}

The study adopted a descriptive survey research design. The study was carried out in four special education centres established in Southeast Nigeria. These special education Centres for the Blind are Afara-Ukwu in Umuahia, Abia State; Basden Memorial Special Education Centre in Isulo, Anambra State; Special Education Centre in Opefia, Izzi L.G.A Ebonyi State; and Special Education Centre in Oji River, Enugu State. The population comprised of 129 respondents, consisting of 125 visually impaired pupils and four librarians. There was no sample size because the population was manageable. Two instruments used for data collection were observation 
checklist which was used to ascertain information resources available for visually impaired pupils and interview guide for librarians. Frequency counts were used to analyse data obtained from the observation checklist while data from the interview was analyzed qualitatively.

\section{Result}

\section{Research Question}

What are the alternative formats of information resources provided for inclusive library services of visually impaired primary school pupils in Southeast Nigeria?

Table 1: Textbooks Provided in Braille

\begin{tabular}{|c|c|c|c|c|c|}
\hline \multirow[b]{2}{*}{ Textbooks/Subjects } & \multicolumn{5}{|c|}{ States } \\
\hline & Abia & Anambra & Ebonyi & Enugu & Total \\
\hline English Language & 43 & Nil & 4 & 23 & 70 \\
\hline Mathematics & 49 & 407 & 4 & 25 & 485 \\
\hline Igbo & Nil & Nil & Nil & Nil & Nil \\
\hline Agricultural Science & Nil & Nil & Nil & Nil & Nil \\
\hline Health Education & Nil & Nil & Nil & Nil & Nil \\
\hline Social Studies & Nil & 98 & Nil & Nil & 98 \\
\hline $\begin{array}{l}\text { Christian religious } \\
\text { knowledge } \\
(\mathrm{CRK}) / \mathrm{Christian} \\
\text { Religious Studies } \\
(\mathrm{CRS})\end{array}$ & 997 & 97 & 917 & 157 & 2,168 \\
\hline Arts & Nil & Nil & Nil & Nil & Nil \\
\hline Computer Science & Nil & Nil & Nil & Nil & Nil \\
\hline Civic Education & Nil & Nil & Nil & Nil & Nil \\
\hline Home Economics & Nil & Nil & Nil & Nil & Nil \\
\hline French & Nil & Nil & Nil & Nil & Nil \\
\hline $\begin{array}{l}\text { Basic Science and } \\
\text { Technology }\end{array}$ & Nil & 18 & Nil & Nil & 18 \\
\hline Total & 1,089 & 620 & 925 & 205 & 2,839 \\
\hline
\end{tabular}


Table 1 shows the provision of information resources in Braille in various subjects. It revealed that the libraries of the special education centres under study lacked Braille resources in many subjects, such as Igbo, agricultural science, health education, arts, computer, civic education, home economics and French. Table 1 also indicates that all the libraries had reasonable Braille collections in Christian Religious Knowledge (CRK). Majority of the Braille collections were Bibles, that is, books of the Bible. They were mainly Braille Bibles donated by foreign philanthropists. Due to the voluminous nature of Braille texts, it is not possible that all the books of the Bible will be transcribed into one volume, but into 66 volumes representing each book of the Bible. The implication of this is that in a situation where a library does not have all the books of the Bible in its Braille collection or where the ones available are old, worn out or torn, it does not have the complete Bible. This was the situation in almost all the libraries visited. Since educational facilities and services should be free for the visually impaired, it means that the responsibility for the provision of resources and facilities for library services rests on the government, state or federal. Under the principles of free education, alternative formats of information resources like Braille, audio and digital forms are supposed to be provided by the government. Contrary to this, the government appears to seldom fulfil this obligation. This was confirmed by all the librarians interviewed. In fact, one of them said, if you wait for the government to provide, it will not come, so you have to solicit help from NGOs, philanthropists, religious groups, etc".

The interview also revealed that there was no policy on the provision or laid down the pattern of provision of resources to special education centres. If there is a policy or principle of provision which may likely spell out the frequency and regularity of provision, it would go a long way to facilitate the provision of alternative formats in the centres.

The librarians also affirmed that soliciting help from Non-Governmental Organizations (NGOs), international agencies, religious organizations and philanthropists has greatly helped in the provision of information resources in the centre libraries. The librarians acknowledged, in particular, the contributions of Niger wives Braille Project, an NGO based in Lagos. This was 
also confirmed by the researcher, who observed that there were Braille textbooks in core subjects of English and Mathematics in all the centre libraries sent by Niger wives.

Table 2: Other Resources Provided in Braille

\begin{tabular}{|l|l|l|l|l|l|}
\hline \multirow{2}{*}{ Resources } & \multicolumn{5}{|l|}{ States } \\
\cline { 2 - 6 } & Abia & Anambra & Ebonyi & Enugu & Total \\
\hline Story books & 180 & 203 & Nil & Nil & $\mathbf{3 8 3}$ \\
\hline Tactile books & 10 & 12 & Nil & Nil & $\mathbf{2 2}$ \\
\hline Dictionaries & Nil & Nil & Nil & Nil & Nil \\
\hline Encyclopedias & Nil & Nil & Nil & Nil & Nil \\
\hline Magazines & Nil & 144 & Nil & Nil & $\mathbf{1 4 4}$ \\
\hline Newspaper & Nil & Nil & Nil & Nil & Nil \\
\hline Total & $\mathbf{1 9 0}$ & $\mathbf{3 5 9}$ & Nil & Nil & $\mathbf{5 4 9}$ \\
\hline
\end{tabular}

Table 2 shows the provision of other information resources in Braille. The table indicates that other information resources were also lacking in Braille in the libraries under study. It was evident from table 2 that besides storybooks and magazines, none of the libraries had Braille newspapers, dictionaries and encyclopedias. Also, it was discovered from the interview that none of the centre libraries had an audio collection.

From the interview, the researcher was made to understand that some of the resources could be produced in-house if they had facilities and personnel. For instance, if there were Braille typists, they could help to transcribe print textbooks into Braille, and if they had tape recorders and recording studios, they could produce audiotapes for the use of visually impaired pupils. One of the librarians complained that the old Braille typists were retired and new ones are not employed. In other words, where the facilities are available, both human and otherwise, provision of information resources can be enhanced through local production. 


\section{Discussion of Result}

The result of the study showed that the special education centre libraries under study lacked Braille textbooks, other information resources in Braille and audio collections. They lacked Braille textbooks in almost all the subjects taught in the schools, including core subjects like English language and mathematics. The few ones available were old editions. This was as a result of the limited provision. None of the libraries had audio materials like talking books, recorded tapes, radios, tape recorders or ICT facilities.

The result is in line with the findings of Adetoro (2011) which indicated that the majority of information materials for visually impaired persons in libraries are not available. Also, the present study agrees with the findings of Eskay and Chima (2013) which revealed that the library lacks most of the materials that can be accessed by visually impaired persons. It also collaborates with Atinmo (2000) who observed that facilities in schools for visually impaired handicapped are scanty; and Babalola and Haliso (2011) who asserted that there were no Braille books in all the academic libraries they studied. Again, the result of the study affirmed the finding of Singh and Moirangthem (2010) which indicated that less number of course books in Braille and less number of course books in audio were the major problems confronting visually impaired students.

Findings from the study also indicated that some of the information resources can be produced locally. With necessary facilities in place, Braille and audio resources can be produced locally, thereby boosting the availability of information resources for visually impaired pupils.

\section{Conclusion}

Evidence from the findings shows that alternative formats of information resources were scantly provided in the libraries under study. Hence, the study concluded that the provision of alternative formats of information resources in special education centre libraries in Southeast Nigeria is inadequate. This has great implication for inclusive library services for visually impaired pupils in the sense that they will not be able to utilize the resources since they cannot access their formats as normally sighted pupils. 


\section{Recommendations}

Based on the findings of this study, the following recommendations were made:

1. The federal or state governments should have written policy statements on the provision of library and information resources for the visually impaired so that the policy may serve as a guide for the provision of information resources to the special education centre libraries.

2. Information resources should be provided in alternative formats readable to the visually impaired pupils. Efforts should be made to provide resources in Braille, audio or ICT formats in all the subjects taught in the schools.

3. The state governments should increase their subventions to the centres so that there will be enough funds to produce some of the resources locally.

\section{References}

Abosi, O., \& Ozoji, E. D. (1985). Educating the blind: a descriptive approach. Ibadan: Spectrum Books.

Adetoro, N. (2010). Reading interest and information needs of persons with visual Impairment in Nigeria. South African Journal of Libraries and Information Science, 76 (1). Retrieved from http://www.sajlis.journals.ac.za/pub/article/download/85/77

Adetoro, N. (2011). Availability and use of information materials by persons with visual Impairment in Nigeria. Information, Society and Justice, 4(2), 5 - 18. Retrieved from http://www.ajol.info/index.php/ajlais/article.

Ajani, O. (n.d.). Improving life for visually impaired persons rests in education in Kwara State Nigeria.

Ajobiewe, T. (1999).Developing library information policy for persons with visual impairment in developing countries. Retrieved from http://icevi.org/publications/icevi_wc20060 3\%20\%20\%20access\%20_to_\%20literacy_th

Alemna, A. (n.d.). Library Provision for the Blind in Africa. Retrieved fromhttp://forge.fhpotsdam.de/ IFLA/INSPEL/93-4alan

Atinmo, M. I. (2000). Including the Excluded: The Challenges of Library and Information Services for Visually Handicapped in Nigeria in the New Millennium. A paper presented at the International Special Education Congress, University of Manchester 24th-28 ${ }^{\text {th }}$ July, 2000. 
Babalola, Y. T., \& Haliso,Y. (2011). Library and information services to the visually impairedthe role of academic libraries. Canadian Social Science, 7(1), 140-147.

Copyright for Visually Impaired Persons (n. d.). Factsheet.

Eguavoen, O. E. I. \& Eniola, M. S. (2007).The relevance of library and information services for the visually impaired in Nigeria. Nigerian Library Link 5(2), 88-96.

Eskay, M \& Chima, J. N. (2013). Library and information service delivery for the blind and physically challenged in University of Nigeria Nsukka Library. European Academic Research, 1(5), 625 - 635.

Federal Republic of Nigeria (2013), National Policy on Education 4th Edition.

Friend, C. (2009). Meeting the needs of the visually impaired persons: What challenges for IP? Paper presented at a meeting hosted by WIPO in Geneva on $13^{\text {th }}$ July 2009. Retrieved from http://www.wipo.int/meetings/en.

Iweha, C. C. (2003). Networking Library Services for Visually Impaired in South Western Nigeria. Journal of Association of Libraries for the Visually Impaired, 2(1), 8 - 17.

Kavitha V., Manumali M. S., Praveen K, \& Heralgi M. M. (2015). Low vision aid-A ray of hope for irreversible visual loss in the pediatric age group. Taiwan J Ophthalmol, 5(2), 63-67. https://doi.org/10.1016/j.tjo.2015.02.002

Naipal S, Rampersad N. (2018). A review of visual impairment. African Vision and Eye Health, 77(1), 1-4. https://doi. org/10.4102/aveh.v77i1.393

National Dissemination Centre for Children with Disabilities (NICHCY) (2012).Visual impairment, including blindness. Disability Facts Sheet 13.

Singh, K. P. \& Moirangthem, E. (2010). Are Indian libraries VIP- friendly? Information use and information seeking behavior of visually impaired people in Delhi libraries. Library Philosophy and Practice. Retrieved from http://digitalcommons.unl.edu

Ugwu, A.B.C.(2008).Elements of special education for higher education. Enugu: Fred-Ogah publishers

Wehmeier, S. ( Ed.). (2000) Oxford Advanced Learner's Dictionary of Current English. Oxford: Oxford University Press. 